\title{
Use of Fluorescence and Reflectance Spectra for Predicting Okra (Abelmoschus esculentus) Yield and Macronutrient Contents of Leaves
}

\author{
Wilfried G. Dibi1,2, Jocelyne Bosson², Irié Casimir Zobi³ , Bi Tra Tiéé, \\ Jérémie T. Zoueu ${ }^{1}$
}

${ }^{1}$ Laboratoire d'Instrumentation Image et Spectroscopie, Unité Mixte de Recherche et d'Innovation en Electricité et Electronique Appliquées, Ecole Supérieure d'Industrie, Institut Nationale Polytechnique Houphouet-Boigny, Yamoussoukro, Côte d'Ivoire ${ }^{2}$ Laboratoire de Physique Fondamentale et Appliquée, Unité de Formation et de Recherche en Sciences Fondamentales et Appliquées, Université Nangui Abrogoua, Abidjan, Côte d'Ivoire

${ }^{3}$ Laboratoire de Pédologie, Ecole Supérieure d'Agronomie, Institut Nationale Polytechnique Houphouet-Boigny, Yamoussoukro, Côte d'Ivoire

Email: jeremie.zoueu@inphb.edu.ci

How to cite this paper: Dibi, W.G., Bosson, J., Zobi, I.C., Tié, B.T. and Zoueu, J.T. (2017) Use of Fluorescence and Reflectance Spectra for Predicting Okra (Abelmoschus esculentus) Yield and Macronutrient Contents of Leaves. Open Journal of Applied Sciences, 7, 537-558

https://doi.org/10.4236/ojapps.2017.710039

Received: May 6, 2017

Accepted: October 27, 2017

Published: October 30, 2017

Copyright $\odot 2017$ by authors and Scientific Research Publishing Inc. This work is licensed under the Creative Commons Attribution International License (CC BY 4.0).

http://creativecommons.org/licenses/by/4.0/

c) (i) Open Access

\begin{abstract}
In-field proximal sensing of most major crops nutrients still remains an economical and technical challenge. For this purpose, the use of effective multi-excitation fluorescence and reflectance wavelengths is explored in this work on Okra plant. Visible-near infrared (400 - $1000 \mathrm{~nm}$ ) reflectance and multi-fluorescence data were collected at leaf scale in a chemically fertilized field by using an USB spectrometer mounted with an Arduino-based LED driver clip. N, P, K and Ca content of samples leaves were measured using reference methods. Average pods yield and leaves macronutrients content were calibrated using IRIV-PLS regression after spectra pretreatments. Single informative wavelengths bands in reflectance, red and far-red fluorescences were selected for building yield and macronutrient content models. We showed that flowering stage was more suitable for yield prediction. Moderately useful macronutrient models were found in Ca content $\left(\mathrm{RPD}_{\text {val }}=1.93, \mathrm{r}_{\mathrm{P}}=0.818\right)$ and potassium content with $\mathrm{RPD}_{\text {val }}=1.8, \mathrm{r}_{\mathrm{P}}=0.88$. $\mathrm{P}$ and $\mathrm{N}$ yielding prediction performance of $\mathrm{RPD}_{\text {val }}=1.61\left(\mathrm{r}_{\mathrm{P}}=0.718\right)$ and $\mathrm{RPD}_{\text {val }}=1.46\left(\mathrm{r}_{\mathrm{P}}=0.56\right)$ respectively were less accurate. This study demonstrates potentiality of fluorescence and reflectance spectroscopy for accurate estimation of leaf macronutrient content and crop yield. High selectivity obtained from resulted spectral bands could lead to the development of reliable, rapid and cost-effective devices for nutrient diagnosis.
\end{abstract}




\section{Keywords}

Proximal Sensing, Fluorescence and Reflectance, Fertilized Field, Macronutrients Content, Pods Yield

\section{Introduction}

In modern agriculture, remote sensing offers efficient tool for enhancing crop production while satisfying sustainability requirements by diagnosing plant nutritional status. Indeed, remote sensing is widely used for early information management about crops fertilization needs, yield forecasting, diseases identification and decision support system from plant leaf to plant canopy and farmland to landscape scale. It is therefore quite rightly that methods derived from remote sensing are highly regarded as key components of Fertilizers Best Management Practices (FBMPs) [1]. According to statistical prevision, world population will grow over 9 billion by 2050 [2] [3]. This situation may increase pressure on world agriculture by the use of greater amount of chemical fertilizer. To overcome future challenges in food supply for this expected world population, locks and limits in the applications of field remote sensing technology have to be solved.

The availability of nutrients represents a limiting parameter of great importance in the evaluation of crop yields [1]. Macronutrients are plant nutrients required in important amounts and are constituted by nitrogen $(\mathrm{N})$, potassium $(\mathrm{K})$, calcium (Ca), magnesium (Mg), phosphorous (P), and sulfur (S) [4]. N, P, K, and $\mathrm{Mg}$ are used in photosynthesis and respiration, whereas $\mathrm{Ca}$ serves to cell division and to cell walls construction [5]. As yet, dynamics of progress on field remote sensing methods currently makes proximal portable or mounted devices directly used in the field to measure $\mathrm{N}$ content with acquisition of fluorescence and reflectance data [6] [7] [8]. Nevertheless, in-field determinations of other mineral nutrients are not as effective as in the case of nitrogen. Nutrients such as $\mathrm{P}, \mathrm{K}$ and S are particularly concerned [3]. About developments in fast spectroscopy for plant mineral analysis, it appears that the use of visible data, combined with the lowest part of near infra-red range had resulted in good calibration models especially in $\mathrm{K}$ [9] as well as in $\mathrm{Ca}$ and $\mathrm{Mg}$ cases [10]. P prediction was poor whereas authors in these studies have employed full spectral range (400 - 1000 $\mathrm{nm}$ ). Using Vis-NIR hyperspectral imaging, Zhang et al. [11] gave acceptable prediction performance of leaf $\mathrm{P}$ macronutrient content in region of interest. Since correlations between polyphenol and mineral content in olive leaves were established in Cetinkaya et al. [12] study, we might expect better prediction performance of leaf macronutrient content by using reflectance additionally with fluorescence data.

Okra (Abelmoschus esculentus (L.) Moench. syn. Hibiscus esculentus L.) is a rich source of protein, vitamin, magnesium, potassium, manganese, sodium, calcium, iron, copper and zinc [13] [14] [15]. Apart from its rich nutritional as- 
pects, it has been reported therapeutic benefits (antidiabetic, antipyretic, diuretic, antispasmodic, etc.) [16]. This vegetable is widely cultivated within tropical and subtropical regions where nutrients requirements for $\mathrm{N}_{2} \mathrm{P}_{2} \mathrm{O}_{5}$ and $\mathrm{K}_{2} \mathrm{O}$ are reported to be 79, 32 and $89 \mathrm{~kg} \cdot \mathrm{ha}^{-1}$ respectively for a yield of $20 \mathrm{t} \cdot \mathrm{ha}^{-1}$ [17]. Although these amounts vary with factors such as: cultivar, plant density, soil type, whether the crop is irrigated or not, the climate and other environmental conditions [18], higher productivity of Okra has been obtained with manure fertilization [19] [20] [21]. In West Africa, the gumbos occupy the second place of vegetable production after tomatoes [22]. Two okra species are cultivated in Ivory Coast: Abelmoschus esculentus and Abelmoschus caillei whose average yield is up to $6 \mathrm{t} \cdot \mathrm{ha}^{-1}$ and potential yields vary between 11 and $13 \mathrm{t} \cdot \mathrm{ha}^{-1}$ [23].

Chemistry or biochemistry data retrieval in spectroscopy measurement is accurately performed in multivariate calibration methods. These procedures are largely known as chemometrics in which efforts are made for developing mathematical and statistical methods to extract relevant, useful and efficient information from raw spectral data. In the optimization of chemometric process, steps such as spectral pretreatment, variable selection and latent factors are highly cases sensitive [24]. Especially in quantitative spectroscopy, single wavelengths selection has been shown to improve precision and accuracy in the calibration process [25]. Moreover, identification of effective wavelengths could offer possibilities to develop non-destructive macronutrient diagnosis devices for crops monitoring. Recently, new trends in chemometrics have highlighted IRIV-PLS methods which demonstrated superior performances in front of other successful variable selection algorithm particularly GA-PLS, MC-UVE-PLS and CARS [26]. IRIV method is part of MPA-based method. This algorithm consists in generating sub-datasets by using Binary Matrix Sampling (BMS) and to find out strongly informative, weakly informative, uninformative and interfering variables, from statistical analysis in the variable space. The most interesting variables retained after backward elimination procedure are those which are strong and weak.

In the present study, we demonstrate potential of multi-excitation fluorescence combined with active reflectance for sensing yield and leaves macronutrients contents. This main objective is twofold: 1) to identify the best phenologic stage for pods yield prediction; and 2) to develop predictive models of N, P, K, and Ca concentration in okra leaves.

\section{Material and Methods}

\subsection{Plant Material, Environmental Conditions and Soil Sampling}

The seeds of gumbo from the variety GB1230 provided by the Centre National de Recherche Agronomique (CNRA) were used in this study. The fertilizer experimentation was conducted at National Polytechnic Institute (INPHB) experimental farm on a manually cleared area of dimensions $39 \mathrm{~m} \times 16 \mathrm{~m}$ located at altitude $229 \mathrm{~m}$, latitude $06^{\circ} 53^{\prime} 17.5^{\prime \prime} \mathrm{N}$ and longitude $05^{\circ} 13^{\prime} 19.6^{\prime \prime} \mathrm{W}$. The climate 
during the experimental period (mid-August to mid-November 2014) on site registered mean values of $27^{\circ} \mathrm{C}$ temperature, $78 \%$ humidity and $1008.5 \mathrm{hPa}$ pressure. Three composite surface soil samples $(0-15 \mathrm{~cm})$ were collected in three main parts of field before sowing. The samples were dried in open air laboratory for 15 days and clods were crushed by hand and gravels removed. Subsequently, the soil was slightly crushed and passed through a $2 \mathrm{~mm}$ calibrated sieve. Analyses were performed on soil fractions smaller than $2 \mathrm{~mm}$. pH was measured in a water-soil (ratio 2/5) solution with a $\mathrm{pH}$-meter. The methods of Walkley and Black [27], Kjeldahl [28] and Thomas [29] were respectively used for the determination of organic carbon, total nitrogen and organic ammonium. Cation exchange capacity (CEC) and exchangeable cations $\left(\mathrm{Ca}^{2+}, \mathrm{Mg}^{2+}, \mathrm{Na}^{+}, \mathrm{K}^{+}\right)$ were extracted by the ammonium acetate method [29]. Total phosphorus is extracted by perchloric acid while assimilable phosphorus was estimated with $\mathrm{Ol}$ sen method modified Dabin. Chemical properties of samples analysed indicate a very low fertile soil with fairly rich organic matter according to the critical classes of chemical elements [30]. The mean soil $\mathrm{pH}$ was 6.2 and some of the other mean values obtained were as follows: total nitrogen, $0.06 \%$; organic carbon, $0.64 \% ; \mathrm{NH}_{4}^{+}, 0.25 \%$; assimilable and available phosphorus, $25 \mathrm{ppm}$ and 294 $\mathrm{ppm}$. CEC mean value is $3.31 \mathrm{cmol} \cdot \mathrm{kg}^{-1}$ and the values obtained for $\mathrm{Ca}^{2+}, \mathrm{Mg}^{2+}$, $\mathrm{K}^{+}$and $\mathrm{Na}^{+}$were $0.829,0.330,0.078$ and $0.083 \mathrm{ppm}$, respectively.

\subsection{Field Experimental Design and Fertilizers Management}

The experiment consisted of three $14 \mathrm{~m} \times 11 \mathrm{~m}$ blocks; each block was divided into twelve plots of $5 \mathrm{~m} \times 1.5 \mathrm{~m}$ including 15 plants, with an alley of $2 \mathrm{~m}$ between the blocks and $1 \mathrm{~m}$ within the plots. The experiment was laid out in a randomised complete block design (RCBD), with twelve treatments, and each treatment was replicated three times. Treatments consisted of a combination of $\mathrm{N}, \mathrm{P}$ and $\mathrm{K}$, each one at three levels supplemented with three reference treatments at the same level for all factors as shown in Table 1.

Fertilizers were prepared using urea $(45 \% \mathrm{~N})$, potassium chloride $\left(60 \% \mathrm{~K}_{2} \mathrm{O}\right)$ and tricalcic phosphate $\left(27 \% \mathrm{P}_{2} \mathrm{O}_{5}\right)$. They were applied once and locally for each plant of a plot at twenty days after sowing corresponding to 2 - 3 leaves stage. Each fertilizer proportion was calculated on the basis of the optimal requirement per plant knowing the elementary surface of application according the formula [31]:

$$
q=\frac{x \times S}{C \times 100}
$$

With $x$ : fertilizer proportion per hectare; $S$ : elementary surface $\left(\mathrm{m}^{2}\right)$; $C$ : content of fertilizing unit (\%).

\subsection{Spectra Acquisition}

The experimental setup was detailed in a previous study [32] and was adaptation from Brydegaard et al. [33] one. It used an USB4000 spectrometer Ocean Optics, 
Table 1. Factor levels and supply modes of fertilization treatments.

\begin{tabular}{ccccc}
\hline Treatment & $\mathbf{N}\left(\mathbf{k g} \cdot \mathbf{h a}^{-1}\right)$ & $\mathbf{P}\left(\mathbf{k g} \cdot \mathbf{h a}^{-1}\right)$ & $\mathbf{K}\left(\mathbf{k g} \cdot \mathbf{h a}^{-1}\right)$ & NPK supply mode \\
\hline $\mathrm{T}_{\mathrm{N}}$ & 0 & 0 & 0 & $(0 ; 0 ; 0)$ \\
$\mathrm{T}_{\mathrm{M}}$ & 39.5 & 7 & 37 & $(1 / 2 ; 1 / 2 ; 1 / 2)$ \\
$\mathrm{T}_{\mathrm{S}}$ & 79 & 14 & 74 & $(1 ; 1 ; 1)$ \\
$\mathrm{T}_{1}$ & 0 & 14 & 74 & $(0 ; 1 ; 1)$ \\
$\mathrm{T}_{2}$ & 26.34 & 14 & 74 & $(1 / 3 ; 1 ; 1)$ \\
$\mathrm{T}_{3}$ & 52.68 & 14 & 74 & $(2 / 3 ; 1 ; 1)$ \\
$\mathrm{T}_{4}$ & 79 & 0 & 74 & $(1 ; 0 ; 1)$ \\
$\mathrm{T}_{5}$ & 79 & 4.67 & 74 & $(1 ; 1 / 3 ; 1)$ \\
$\mathrm{T}_{6}$ & 79 & 9.34 & 74 & $(1 ; 2 / 3 ; 1)$ \\
$\mathrm{T}_{7}$ & 79 & 14 & 0 & $(1 ; 1 ; 0)$ \\
$\mathrm{T}_{8}$ & 79 & 14 & 24.67 & $(1 ; 1 ; 1 / 3)$ \\
$\mathrm{T}_{9}$ & 79 & 14 & 49.34 & $(1 ; 1 ; 2 / 3)$ \\
\hline
\end{tabular}

a laptop and an Arduino microcontroller. The Led clip is composed of three Light-emitting-diodes (Leds) exciting the fluorescence at $380 \mathrm{~nm}$ (UV), $520 \mathrm{~nm}$ (green) and $630 \mathrm{~nm}$ (red) while the emitted fluorescence light was detected in the red and far-red spectral regions using a long-pass filter at $650 \mathrm{~nm}$. A white LED emitting (400 - $700 \mathrm{~nm})$ was utilized for reflectance measurement. A schematic drawing of the experimental setup used is given in Figure 1.

\subsection{Spectra Preprocessing}

Before starting chemometrics analyzes, three preprocessing methods namely gaussian filtering, standard normal variate transformation (SNV) and second derivation were applied to each spectra type (fluorescence with red, green, UV Led and reflectance with white Led). SNV standardized each spectrum by its own average and standard deviation for quantity correction [34]. It changes relation between peaks and enhances noisy signals. If prior to SNV one peak varies, after SNV all peaks vary. Derivatives are a form of high-pass filter and frequency-dependent scaling and are often used when lower-frequency (i.e., smooth and broad) features such as baselines are interferences and higher-frequency (i.e., sharp and narrow) features contain the signal of interest. Hruschka [35] showed that the derivative transformation methods could enhance the signal-to-noise ratio and resolve overlapping absorption features. Additionally, the derivative hyperspectra of crops could also eliminate or minimize the effects of leaf water content, noise, and atmosphere on $\mathrm{N}$ estimations of crops. Rieppo et al. [36] noted that second derivative spectroscopy allows more specific identification of small and nearby lying absorption peaks which are not resolved in the original spectrum, thereby offering means to increase the specificity of absorption peaks for certain molecules of the tissue. 


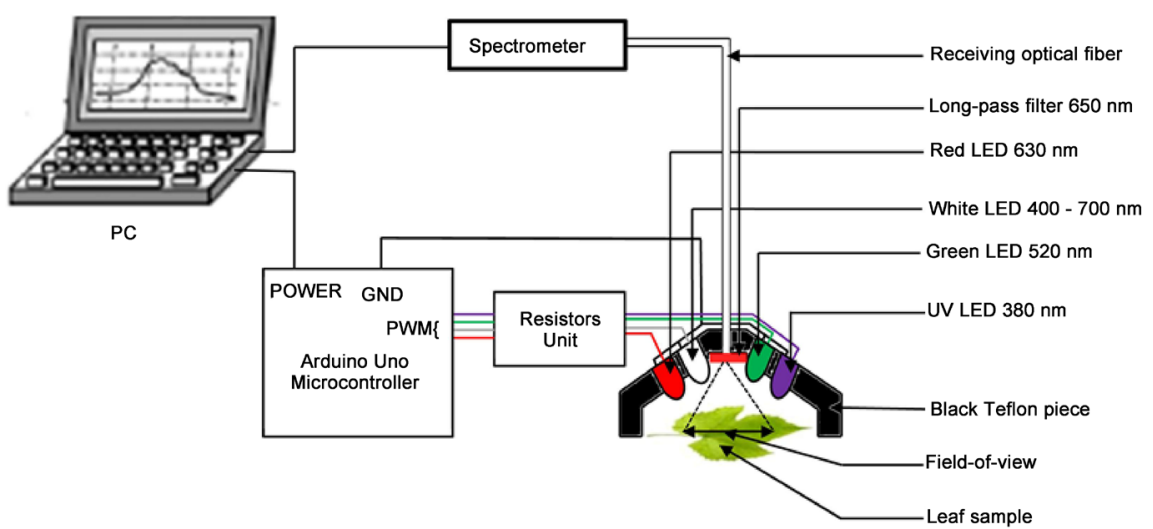

Figure 1. Schematic drawing of the experimental setup used for spectra acquisition.

\subsection{Content Measurement of N, P, K and Ca}

After the spectral measurement of leaves from each experimental plot in the field, those leaves were collected and destructively sampled to determine their macronutrient content. Chemical analysis of plants tissue were conducted in the Laboratoire de Pédologie and Laboratoire des Procédés Industriels, de Synthèses, de l'Environnement et des Énergies nouvelles (LAPISEN) at National Polytechnic Institute Houphouet Boigny (INPHB). The reference method for nitrogen content was the Kjeldahl [28]. Dried and crushed leaves samples of $0.4 \mathrm{~g}$ are mineralized and put in solution with nitric and chlorhydric acid [37]. Phosphorus content was determined by UV/Vis Spectrometer Jasco V-530 Inc. Calcium and potassium content was determined by flame atomic absorption spectrometry air-acetylene using spectrophotometer VARIAN type AA20, Australia [38].

\subsection{Chemometric Analysis}

A general workflow procedure has guided the development of macronutrient models. In this context, Figure 2 gives a substantial overview. Four main methods were employed.

In chemometric process, initial samples are firstly screened with Monte Carlo method for detecting potential outliers. After eliminating these dubious data, the remaining samples are splitted in training and test data according to Kennard-Stone data partition method. These two subsets are used as input parameters in IRIV algorithm for selecting optimal reflectance and fluorescence wavelengths. Finally, PLSR using normal samples was conducted with optimal spectral data obtained from IRIV process. Then, calibration models and their validation are generated.

\subsubsection{Monte Carlo Method of Outliers Detection}

Applied at first on QSAR/QSPR data set, the MC method is proved to be an approach for diagnosing dubious samples contained in raw dataset [39]. This method was used to increase model performance prediction and consisted in studying the distribution of prediction errors of each sample obtained from original dataset. The number of principal component was firstly determined using 


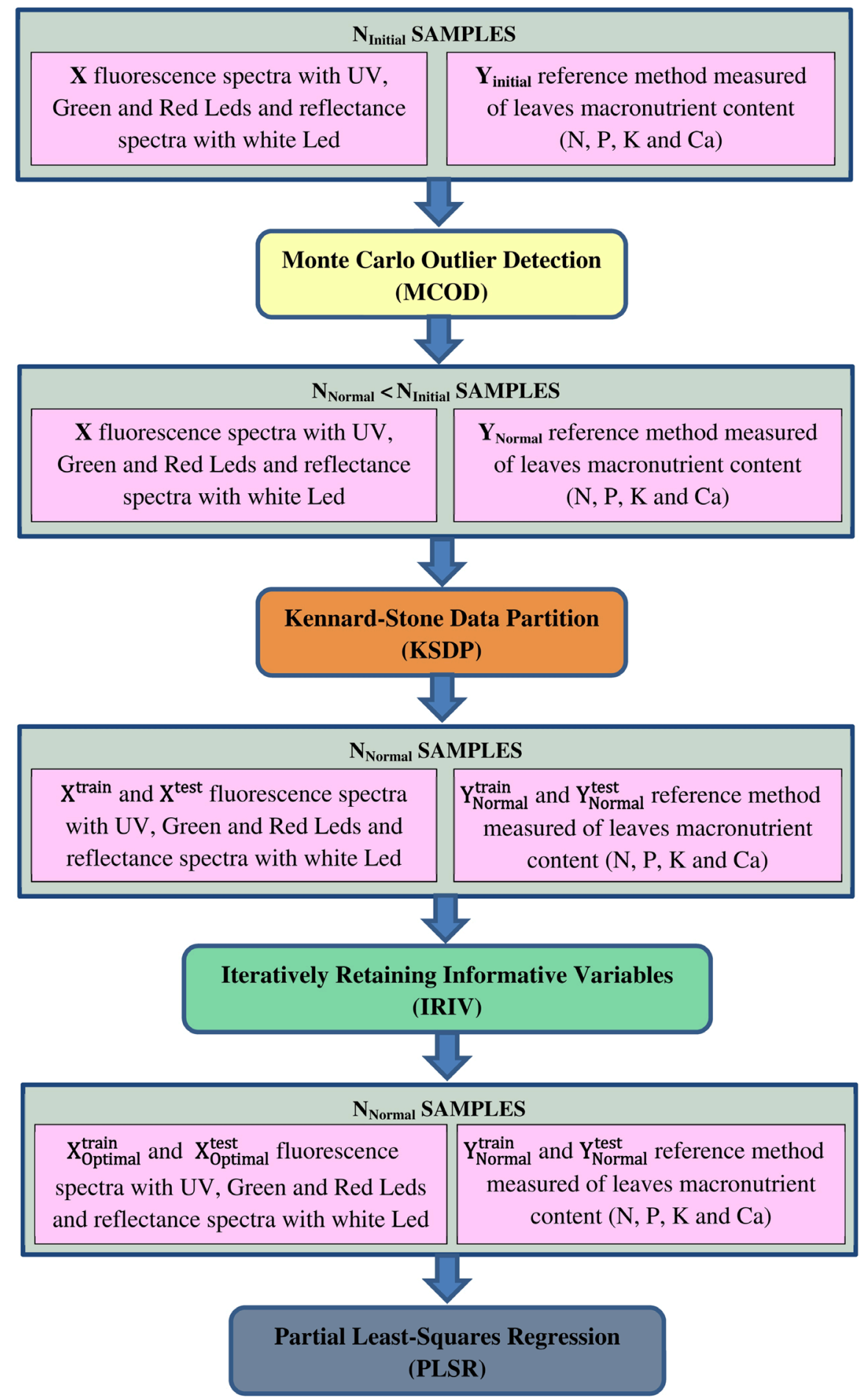

Figure 2. Flow-chart of chemometric method in macronutrient models development.

cross-validation in PLS and PCR method. For a given number of iteration, 70\% to $90 \%$ samples are randomly chosen from whole dataset and used to calibrate the model. This model is tested on the remaining samples and prediction error on each sample is computed and stored. The statistical distribution of these errors was evaluated through mean value $m(j)$ and the standard deviation $s(j)$ 
for the $j$ th sample. The result of variance of residuals versus mean of residuals on all samples are plotted in a diagram which is able to differentiate three types of outliers and normal samples according to computed statistical sample coordinate as follows:

$$
\begin{gathered}
m(j)=\frac{1}{k} \sum_{i=1}^{k} \operatorname{error}(i) \\
s(j)=\left(\frac{1}{k-1} \sum_{i=1}^{k}(\operatorname{error}(i)-m(j))^{2}\right)^{1 / 2}
\end{gathered}
$$

\subsubsection{Kennard-Stone Data Partition Approach}

Kennard and Stone [40] approach offers a practical solution to split a study population into a training set and a testing set. The $K S$ algorithm consists in selecting samples by evaluating the Euclidian distance $E D_{x}(p, q) x$-vectors of each pair $(p, q)$ of samples according to the following formula below [40] [41] [42] [43].

$$
E D_{x}(p, q)=\sqrt{\sum_{j=1}^{N}\left[x_{p}(j)-x_{q}(j)\right]^{2}}, p, q \in[1, M]
$$

In Equation (4), $N$ is the number variables in $x$ and $M$ is the number of samples. $x_{p}(j)$ and $x_{q}(j)$ are the $j$ th variable for samples $p$ and $q$, respectively. At each iteration, the algorithm selects the point furthest from the points already retained. This process is executed again until selecting the $N$ desired points. The aim of $K S$ algorithm is to find a representative and uniform subset selection of data.

\subsubsection{IRIV Selection Method}

IRIV stands for Iteratively Retaining Informative Variable. This method was developed by considering the data matrix $x$ which contains $N$ samples in rows and $p$ variables in columns, and $y$, of size $N \times 1$, denoting the measured property of interest [26]. Binary matrix sampling consists of generating a binary matrix $M$ of dimension $K \times P$ which is assigned randomly with the number " 1 " or " 0 " to each column. Each row of the binary matrix corresponds to an individual sampling, where " 1 " denotes the samples selected for modeling and " 0 " for unselected samples. By the process of inclusion and exclusion of the binary values " 1 " or " 0 ", the matrix $M_{1}$ is obtained by changing for the first column all " 0 " to " 1 " and vice versa. Then a subset (variable ith column) is evaluated by PLS and a statistical distribution of the RMSECV at inclusion and exclusion is obtained. These statistical distributions of RMSECV for a variable are tested with the assumption that the distribution of the data is the same for two groups in order to identify the importance of this variable. Mann-Whitney's non-parametric U-test is used for this purpose. According to the $p$-value obtained, the variables are classified into 4 categories: highly informative, weakly informative, interfering and non-informative. After removing the last two types of variables, a new subset is generated and the same calculation cycle is repeated. At the end of the iteration, when no non-informative or interfering variable exists, a background 
elimination procedure is carried out to output the optimal variables selected.

\subsubsection{PLSR Analysis}

Partial Least-Squares Regression (PLSR) has become a standard tool in chemometry and is widely applied in various fields such as chemical [44], economical [45], biological [46] [47] [48] and social sciences [49]. In this study, PLSR analysis was performed to establish regression models for the determination of the target chemical concentrations measured in fresh gumbo leaves (variable matrix $Y$ ) based on the optimal variable spectra (variable matrix $X$ ) obtained from the IRIV process. Autoscale technique was the main preprocessing method employed for X-Block and Y-Block. Cross-validation method was based on venetian blinds using 5-folds split for $\mathrm{K}$ model, 6-folds for $\mathrm{N}$ and $\mathrm{Ca}$ models, then 8-fold for $\mathrm{P}$ one. Models for macronutrients content developed were built with a number of samples in calibration set comprising $67 \%$ to $75 \%$ of whole data.

\subsection{Model Evaluation}

To check whether the model satisfy to standard qualities in multivariate regression, we referred to some common chemometrics terms: Bias, Ratio Performance Deviation (RPD), correlation coefficient in calibration $\left(\mathrm{R}_{C}\right)$ and prediction $\left(\mathrm{R}_{\mathrm{P}}\right)$, root mean square error (RMSE) of calibration (RMSEC) and prediction (RMSEP). According to Williams [50], correlation coefficient, SEP, bias and RPD are the most useful statistics for evaluating calibration performance. Moreover, using Malley et al. [51] criteria based on correlation coefficient and RPD on validation data, we are able to classify the success of predictions. Indeed these criteria propose a guideline scale for describing the performance of calibrations for environmental samples as follows: Excellent, $R_{\mathrm{P}}>0.95, \mathrm{RPD}>4$; Successful, $R_{\mathrm{P}}=0.9-0.95$, RPD 3 - 4; Moderately Successful, $R_{\mathrm{P}}=0.8-0.9$, RPD 2.25 - 3; and Moderately Useful, $R_{\mathrm{p}}=0.7-0.8$, RPD $1.75-2.25$.

\subsection{Software}

All methods have required Matlab software for computations (version 2015a, the Math Works, Inc.). Chemometric analyses have respectively used libpls and IRIV codes freely provided by Li et al. [52] at http://www.libpls.net and Yun et al. [26] at http://code.google.com/p/multivariate-calibration/downloads/list. Computations were carried out on a general-purpose computer with intel ${ }^{\circledR}$ Core (TM) i3-4160 3.6 $\mathrm{GHz} \mathrm{CPU}$ and $16 \mathrm{~GB}$ of RAM where Microsoft Windows 10 was employed as operating system. PLSR was performed using the PLS Toolbox (V. 8.1, Eigenvector Research, Inc., Wenatchee, USA).

\section{Results and Discussion}

\subsection{Reference Data of Macronutrients Content and Okra Yield}

Maximum yield of approximatively 6 - $7 \mathrm{t} / \mathrm{ha}$ obtained in this study of Okra farm experimentation can be justified by a harvest period of only 45 days rather 
than the three months envisage don the employed variety. This yield is particularly suitable according to others experimental farming carried out on the same variety. On the level of nutritional information, both calibration and validation set covered large value ranges. This is due to fertilization design, leaf position and period of time run out during the first and the second acquisition. Moustakas et al. [53] showed that in Okra (Abelmoschus esculentus (L.) Moench.) major nutrient uptake was rapidly increasing between 30 and 60 days after transplanting. This ensures higher concentration value, mainly observed in the second acquisition samples set. Table 2 summarizes yield and macronutrient contents used in this study.

\subsection{Spectral Features of Preprocessed Okra Fresh Leaves}

After SNV and $2^{\text {nd }}$ derivative, the preprocessed spectra are successively combined to form a single spectrum. Autoscale of those combinations of multi fluorescence and reflectance spectra is shown in Figure 3.

On Figure 3 examination, we can notice enhanced peaks in number and intensity more in fluorescence spectra than in reflectance one. These peaks may have been caused by different contents of nutritional parameters as derivative spectroscopy has been proved to be an efficient method which enhances resolution in spectroscopic data [54].

\subsection{Outliers Detection Using MC Method}

Analysis of Figure 4 shows that there are different outliers in number and type by chemical content. Some similar outliers are found in calcium as well as in potassium and phosphorus data.

Nitrogen samples are very low because chemical analysis at first data acquisition performed on $\mathrm{P}, \mathrm{K}$ and $\mathrm{Ca}$ has consumed almost samples. Besides some of

Table 2. Reference data parameters. Yield data is expressed in $\mathrm{kg} / \mathrm{ha}$. $\mathrm{N}$ is shown as percentage of dry matter and $\mathrm{P}, \mathrm{K}$, Ca values are given in $\mathrm{mg} / \mathrm{kg}$ of dry matter.

\begin{tabular}{cccccccc}
\hline & Parameter & Yield 1 & Yield 2 & N & P & K & Ca \\
\hline & $n$ & 24 & 24 & 13 & 32 & 30 & 32 \\
Calibration & Min & 201 & 201 & 1.6 & 666.67 & 8932 & 6793 \\
& Max & 7868.6 & 7868.6 & 3.64 & 2678.34 & 204,966 & 663,699 \\
& Mean & 3396.5 & 3396.5 & 2.927 & 1495.73 & $95,177.4$ & 217,464 \\
& Std & 2353.7 & 2353.7 & 0.575 & 577.48 & $66,560.1$ & 199,068 \\
& $n$ & 12 & 12 & 5 & 14 & 10 & 15 \\
& Malidation & 1455.2 & 1455.2 & 2.8 & 800 & 48918.7 & 64793 \\
& Max & 4823.6 & 4823.6 & 4.03 & 2161.67 & $181,333.3$ & 696,999 \\
& Mean & 3076.3 & 3076.3 & 3.328 & 1580.47 & $112,005.3$ & 353,135 \\
& Std & 946.3 & 946.3 & 0.47 & 446.32 & 51,573 & 207,257 \\
\hline
\end{tabular}




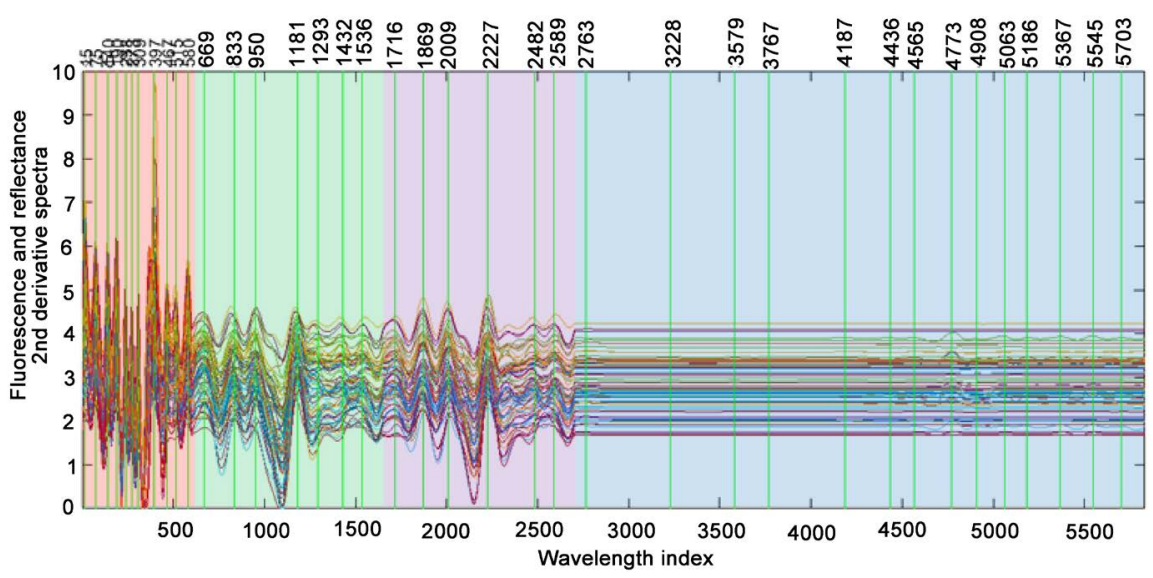

Figure 3. Combination of preprocessed multi-fluorescences and reflectance spectra obtained successively by $\mathrm{SNV}, 2^{\text {nd }}$ derivative and autoscale. Vertical green lines indicate peaks. Red, green and violet bands respectively correspond to fluorescence emission in $650-850 \mathrm{~nm}$ region by using red, green and violet Led excitation sources. Blue color band is related to reflectance in $400-1000 \mathrm{~nm}$ region with white Led source.

the samples intended for nitrogen analysis have been loosed during drying oven process. Using the Monte Carlo method, we have left out 6, 19, 21 and 26 samples respectively in nitrogen, phosphorus, calcium and potassium data as shown below.

\subsection{Developpement and Validation of Calibration Models}

\subsubsection{Okra Best Phenologic Stage for Fruits Yield Prediction}

After partitionning yield and spectra data with Kennard-Stone algorithm, we applied IRIV algorithm to find out the best phenologic stage for pods yield prediction. YieldAcq1 is related to first spectra acquisition at vegetative stage and YieldAcq2 is concerned with second acquisition at flowering growth stage. Model related to YieldAcq2 has RMSEC and RMSEP values lower than the one developed using spectra acquired at vegetative stage in YieldAcq1. YieldAcq2 model is established using wavelengths in fluorescence under red, green and UV excitations, and variables in reflectance bands while YieldAcq1 only used fluorescence variables under UV excitation (Table 3).

Results of IRIV modelling respectively gave RMSEP and RMSEC values of $1736.9 \mathrm{~kg} / \mathrm{ha}$ and $1547.3 \mathrm{~kg} / \mathrm{ha}$ for YieldAcq2 against $2523.3 \mathrm{~kg} / \mathrm{ha}$ and 1627.4 $\mathrm{kg} / \mathrm{ha}$ for YieldAcq1. Good model tendency is to have high $\mathrm{R}_{c}$ and $\mathrm{R}_{\mathrm{P}}$ values while RMSEC and RMSEP values are low [55] [56]. Hence, YieldAcq2 root mean square error on calibration and validation are more appropriate. This result agrees with Weber et al. [57] one. Their study on grain maize prediction by using leaves reflectance have indicated that coefficients of determination $\left(\mathrm{r}^{2}\right)$ between predicted and actual grain yield were highest for measurements conducted at anthesis and milk-grain stage. Thus, we conclude that fluorescence and reflectance measured at flowering stage are suitable for gumbo fruits yield prediction. 


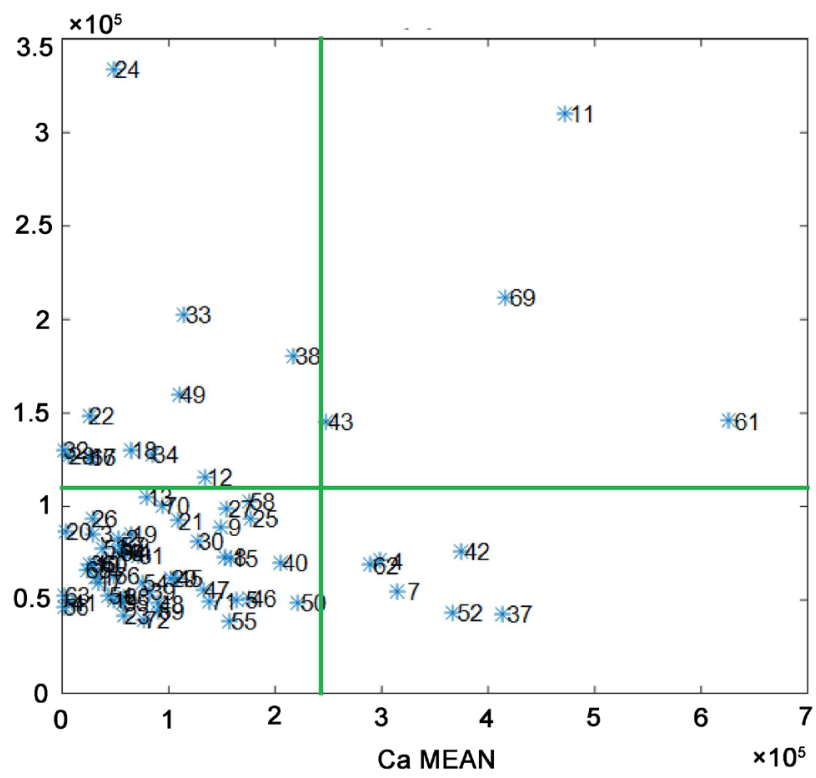

(a)

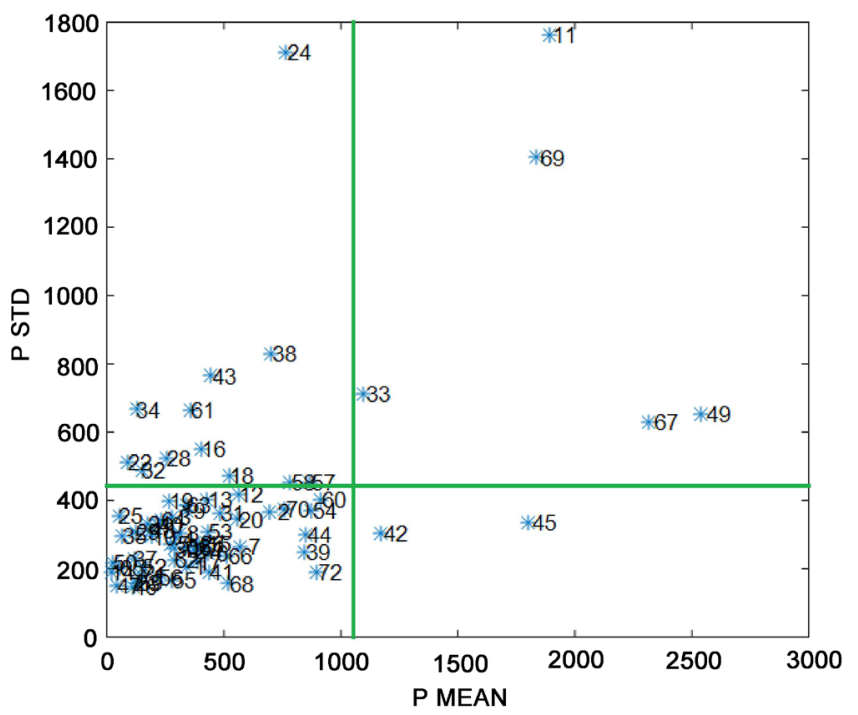

(c)

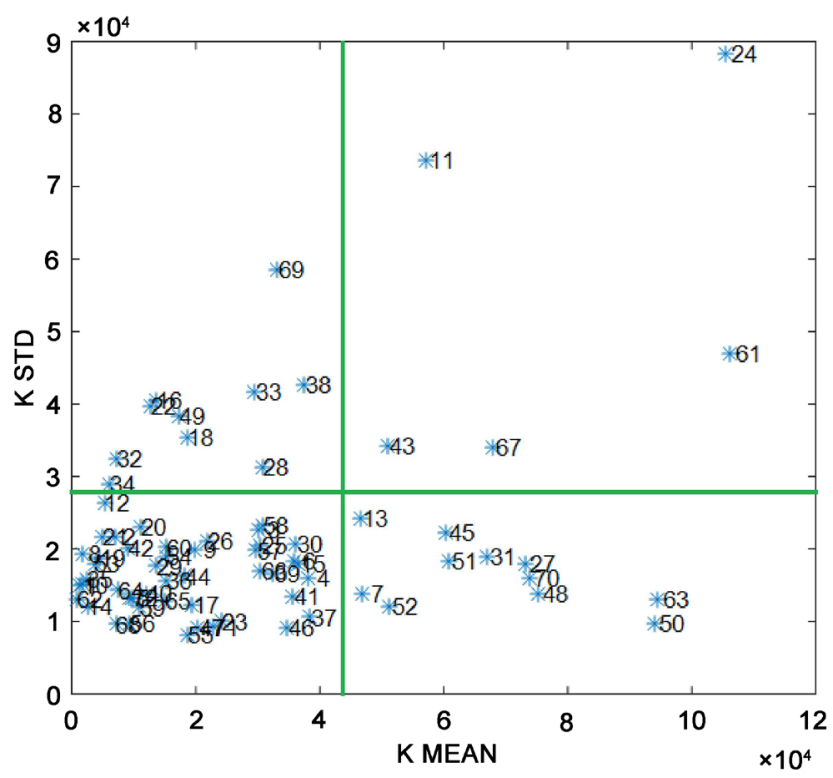

(b)

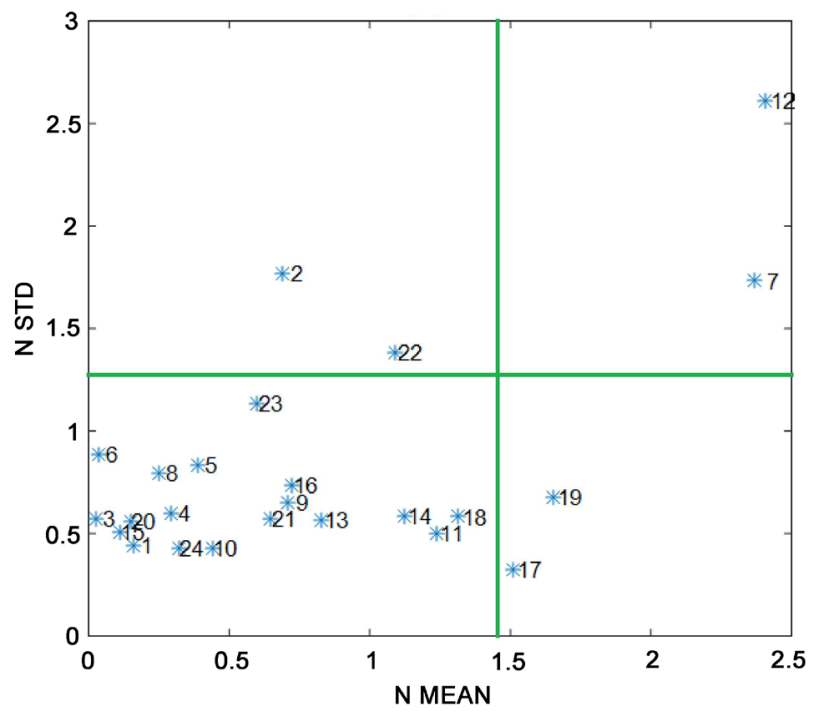

(d)

Figure 4. Schematic diagram differentiating outliers and normal samples in calcium (a); potassium (b); phosphorus (c); and nitrogen content $(\mathrm{d})$.

\subsubsection{Prediction of Macronutrient Content}

Table 4 summaries the calibration and validation statistics for $\mathrm{N}, \mathrm{P}, \mathrm{K}$ and $\mathrm{Ca}$ macronutrients. Minimum $r_{C}$ value of 0.92 and $R P D_{\text {cal }}$ value of 2.35 indicate high efficiency in overall model calibration. Models also appear robust as $r_{p}$ values stand in 0.79 - 0.86 range.

$\mathrm{Ca}$ and $\mathrm{K}$ models have better calibration success according to RPD value calculated on validation data. These models are classify as moderately useful according to Malley et al. [51] criteria although the $\mathrm{r}_{\mathrm{p}}$ coefficients above 0.8 were high enough to be considered moderately successful (Table 4).Potassium model has the highest correlation values with $r_{C}=0.899$ and $r_{P}=0.885$. RPD values in 
Table 3. Selected effective wavelengths from $2^{\text {nd }}$ derivative spectra.

\begin{tabular}{|c|c|c|c|c|c|}
\hline $\begin{array}{l}\text { Nutrient } \\
\text { or yield } \\
\text { parameter }\end{array}$ & $\begin{array}{c}\text { Variables } \\
\text { number }\end{array}$ & $\begin{array}{c}\text { Fluorescence } \\
\text { R630 (nm) }\end{array}$ & $\begin{array}{c}\text { Fluorescence } \\
\text { G520 (nm) }\end{array}$ & $\begin{array}{l}\text { Fluorescence } \\
\text { UV375 (nm) }\end{array}$ & $\begin{array}{c}\text { Reflectance } \\
\text { white Led (nm) }\end{array}$ \\
\hline $\mathbf{N}$ & 7 & & & & $570-571 ; 607-608$ \\
\hline $\mathbf{P}$ & 13 & 758 - 759; 772; 783; & $680 ; 810$ & $744 ; 817$ & $973-974$ \\
\hline $\mathrm{K}$ & 95 & 781 - 782; & $673 ; 835$ - 836; & $\begin{array}{c}681-683 \\
759 ; 799\end{array}$ & $\begin{array}{c}418-421 ; 450-456 \\
754 ; 767-768 ; \\
824 ; 942-944 \\
957-959 ; 972-974\end{array}$ \\
\hline $\mathrm{Ca}$ & 6 & & & & $649-654$ \\
\hline YieldAcq1 & 5 & $703 ; 767$ & & & \\
\hline YieldAcq2 & 119 & $692 ; 733$ & 677 & $669-670$ & $\begin{array}{l}467-476 ; 652-657 \\
858-860 ; 980-987\end{array}$ \\
\hline
\end{tabular}

Table 4. Results of PLS prediction of macronutrient.

\begin{tabular}{|c|c|c|c|c|}
\hline Parameters & $\mathbf{N}$ & $\mathbf{P}$ & $\mathrm{K}$ & $\mathrm{Ca}$ \\
\hline \multicolumn{5}{|l|}{ Model } \\
\hline N LV & 5 & 10 & 8 & 7 \\
\hline Pre-Processing X-Block & \multicolumn{4}{|c|}{ Autoscale } \\
\hline Pre-Processing Y-Block & \multicolumn{4}{|c|}{ Autoscale } \\
\hline RMSEC & 0.1490 & 164.19 & 10076 & 55422 \\
\hline$r_{C}^{2}$ & 0.9270 & 0.9170 & 0.9760 & 0.9200 \\
\hline$r_{C V}^{2}$ & 0.8570 & 0.7890 & 0.8990 & 0.8650 \\
\hline $\mathrm{RPD}_{\text {cal }}$ & 3.86 & 2.35 & 6.6 & 3.59 \\
\hline \multicolumn{5}{|l|}{ Test } \\
\hline$r_{p}^{2}$ & 0.570 & 0.718 & 0.885 & 0.818 \\
\hline RMSEP & 0.320 & 276.45 & 28609.7 & 107162 \\
\hline $\mathrm{RPD}_{\mathrm{val}}$ & 1.468 & 1.614 & 1.802 & 1.934 \\
\hline
\end{tabular}

both models (1.9 for Caand 1.8 for $\mathrm{K}$ ) are close to 2. Potassium $\mathrm{RPD}_{\text {val }}$ value is similar to Villatoro-Pulido et al. [58], Ward et al. [59] and Aldana et al. [60] results ones in which $400-2500 \mathrm{~nm}$ spectral ranges were used to predict dry ground leaves samples. Highest $\mathrm{RPD}_{\text {val }}$ value of 6.1 for potassium has been found in Menesatti et al. [10] work using VIS-NIR in 400 - 1000 nmon fresh orange leaves but $\mathrm{Ca} \mathrm{RPD}_{\mathrm{val}}=1.5$ was low.

In Figure 5, predicted versus measured plots for calcium and potassium show representative data range. The validation set presents significant bias whereas calibration ones equals zero. Variables selected in our study are very small for calcium model (6 variables) while potassium model uses 95 wavelengths: all 


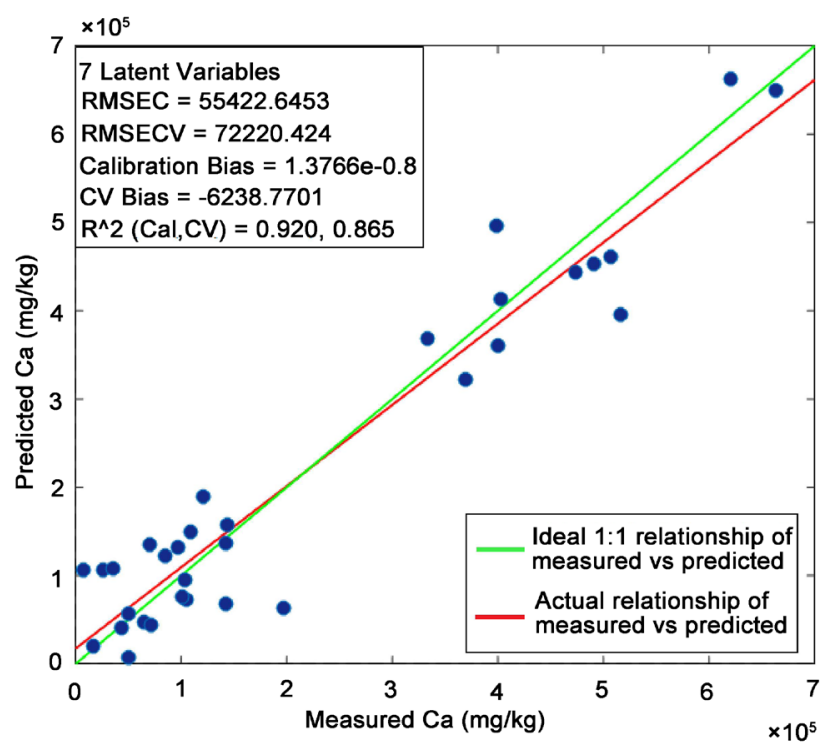

(a)

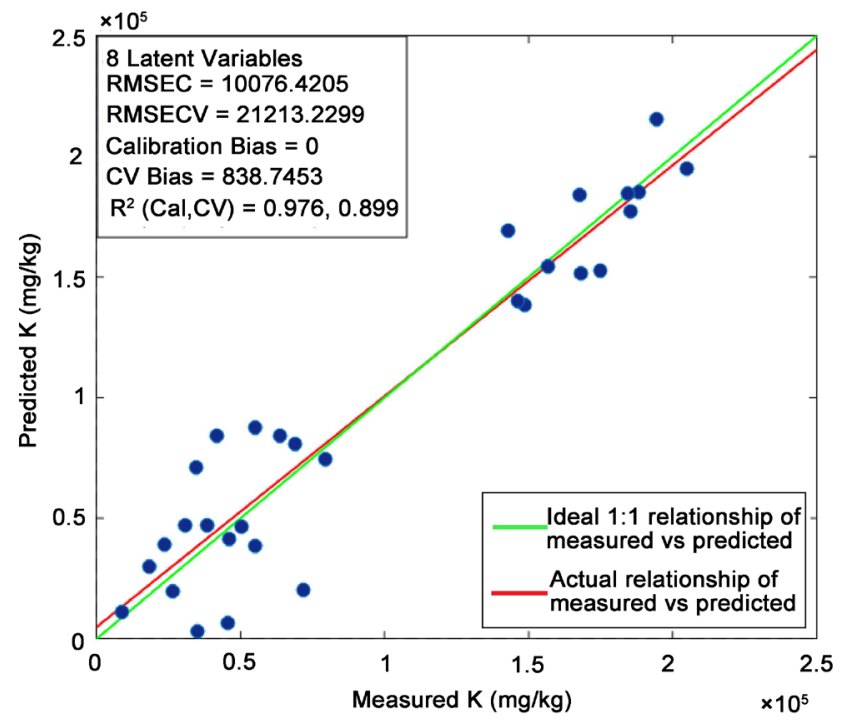

(c)

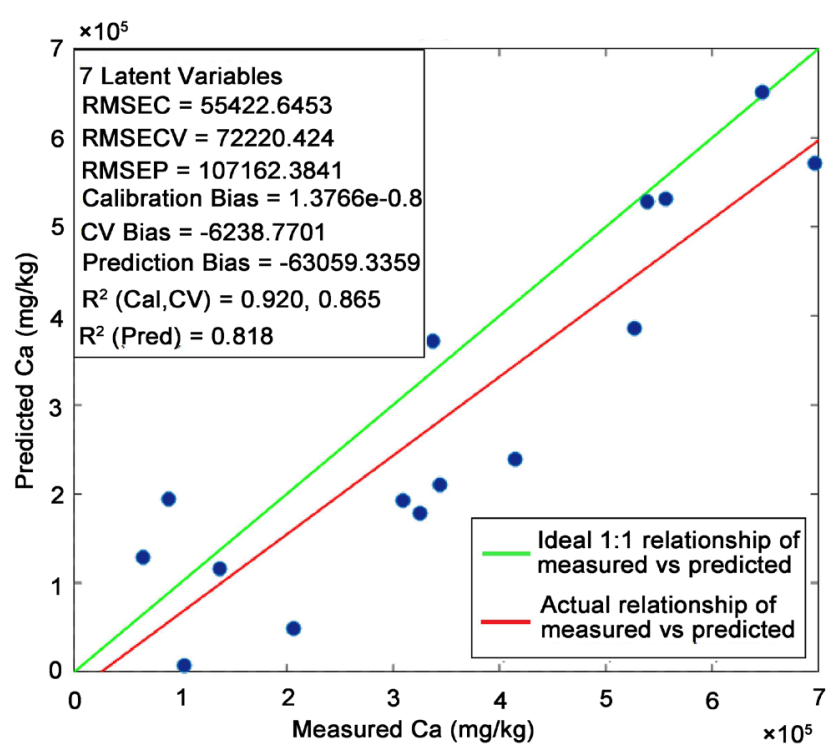

(b)

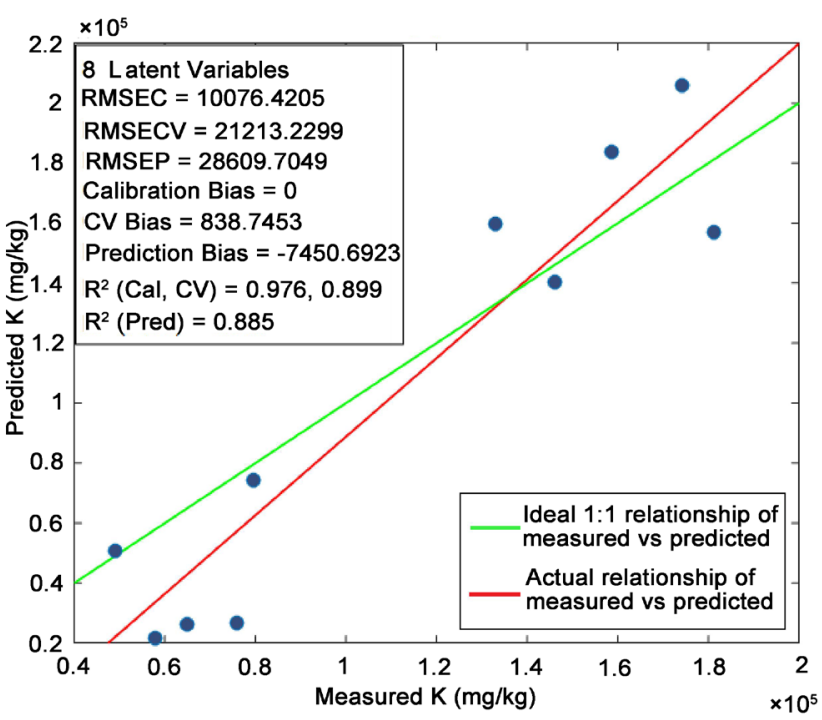

(d)

Figure 5. Predicted vs. reference plots and model data for: (a) Calcium calibration; (b) Calcium validation; (c) Potassium calibration; (d) Potassium validation.

fluorescence emission signals in red and far-red bands with excitations in red (781 - $782 \mathrm{~nm})$, green $(673 ; 835-836 \mathrm{~nm})$, UV (681 - 683; 759; $799 \mathrm{~nm})$ and large number of reflectance variables.

Klančnik et al. [61] has shown that reflectance spectra were significantly affected by the Ca concentrations which were mostly accumulated in the mesophyll, and particularly in the areas of the vascular bundles. In this case, our study confirms but much better precises the relations between Ca content and most sensitive reflectance bands located in 649 - $654 \mathrm{~nm}$ range. In the case of potassium, the use of fluorescence in red, green, UV light for model building suggests that variation in this nutrient could elicit changes in flavonol, anthocyanin and 
chlorophyll pigments. These results at leaf level are essentially new for flavonol and anthocyanin content. Increase of anthocyanin content in petals due to potassium uptake has been reported [62]. An increase in chlorophyll, and carotenoid contents was also found as a result of potassium treatments excepting for higher concentration [63]. Calcium and potassium models developed denote strong relevance of the selected wavelengths in fluorescence and reflectance mode that could be used for accuracy measurements of leaf calcium and potassium content.

In contrast, the two last models have low performance prediction owing to their $\mathrm{RPD}_{\text {val }}$ values (1.6 for $\mathrm{P}$ and 1.47 for $\mathrm{N}$ ). Nevertheless, the correlation coefficient in phosphorus prediction around 0.72 represents a satisfactory result since poor prediction ability has been reported in previous investigations [10] [59] [64].

Our result in validation set is comparatively equivalent to Zhang et al. [11] phosphorus prediction when they applied hyperspectral imaging technique in VIS-NIR region (380 - $1030 \mathrm{~nm}$ ) on oilseed rape leaves region of interest. Photosynthetic process largely relies on $\mathrm{P}$ containing compounds [65]. P plays a very important role in the composition of chloroplast and photosynthesis and can be directly involved in the assimilation of photosynthesis and photosynthetic phosphorylation [66]. Thus, photosynthesis is sensitive to low $\mathrm{P}$ stress [67]. Variation in $\mathrm{P}$ content affects chlorophyll a fluorescence response with red light excitation. Our findings also show that phosphorus level concomitantly induced variation in flavonol and anthocyanin content respectively responsible of fluorescence in far-red band under UV $(375 \mathrm{~nm})$ and green $(520 \mathrm{~nm})$ light excitation. Involved wavelengths are mentioned in Table 3. This result corroborates Ulrychová et Sosnová [68] study which shows that phosphorus deficiency result in an evident increase of anthocyanin content. But, Stewart et al. [69] work attributed increase of total flavonol in tomato plant leaves mainly to nitrogen deficiency than to low phosphorus content.

In the case of nitrogen prediction, most investigations have established high accuracy measurements by using reflectance spectra [70] [71] [72]. In this work, 7 optimal variables in $2^{\text {nd }}$ derivative reflectance bands $(570-571 ; 607-608 \mathrm{~nm})$ are the most informative regions for nitrogen model development. These regions correspond to negative slope in green-yellow leaf reflectance and are related to LUE (Light Use Efficiency) green spectral region. They represent high selectivity for nitrogen wavelength screening in light of previous studies. Few sampling explains low value of correlation coefficient and RPD on validation. Nevertheless, according to Wang model performance classification [73], RPD and correlation coefficient values respectively in $1.4-2$ and $0.5-0.75$ ranges are acceptable. As shown in Figure 6, the calibration models are representative of macronutrient content variation and present in test set lower bias than calcium and potassium models.

From this study, we can conclude reasonable prediction performance of macronutrient models using combined fluorescence and reflectance informative 


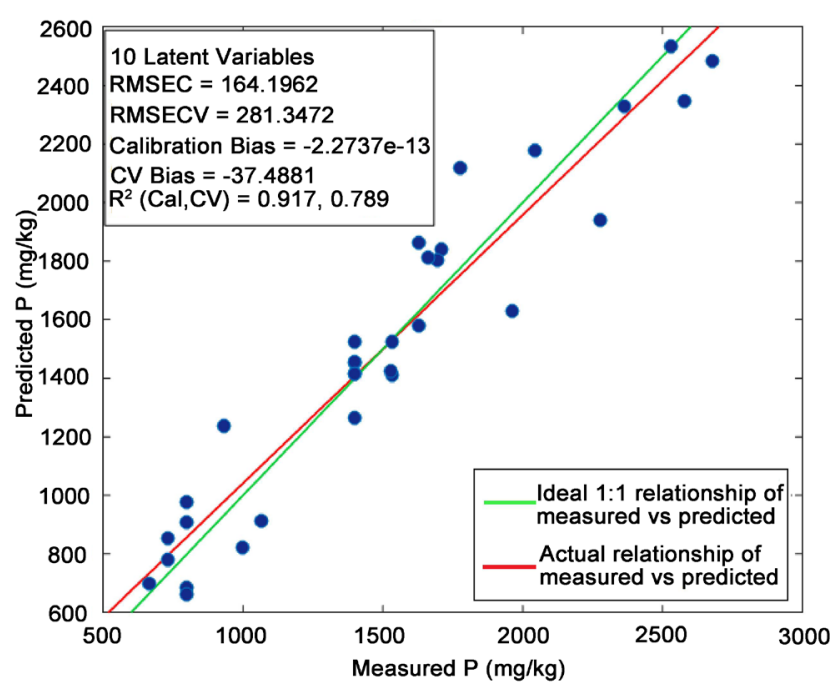

(a)

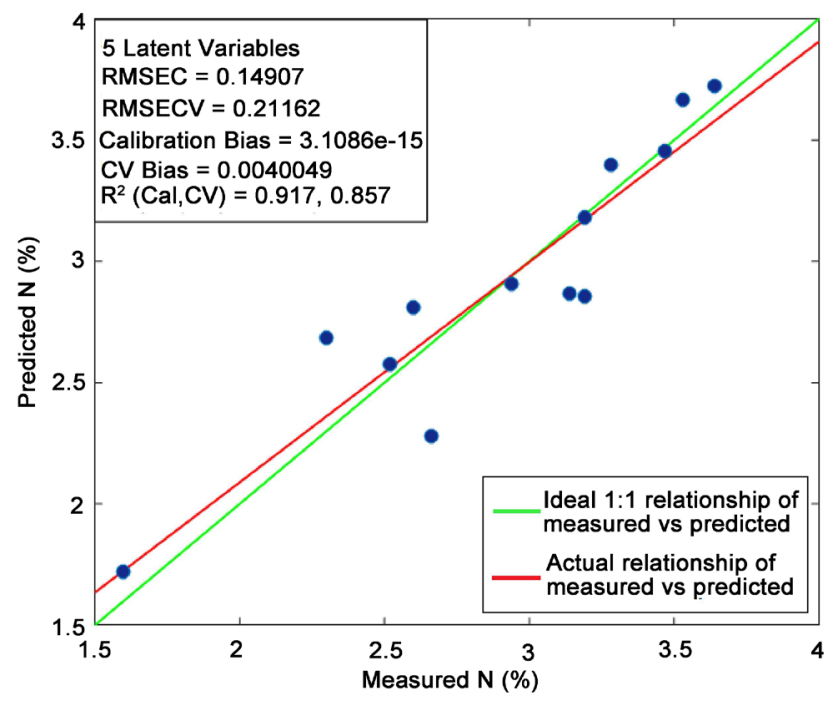

(c)

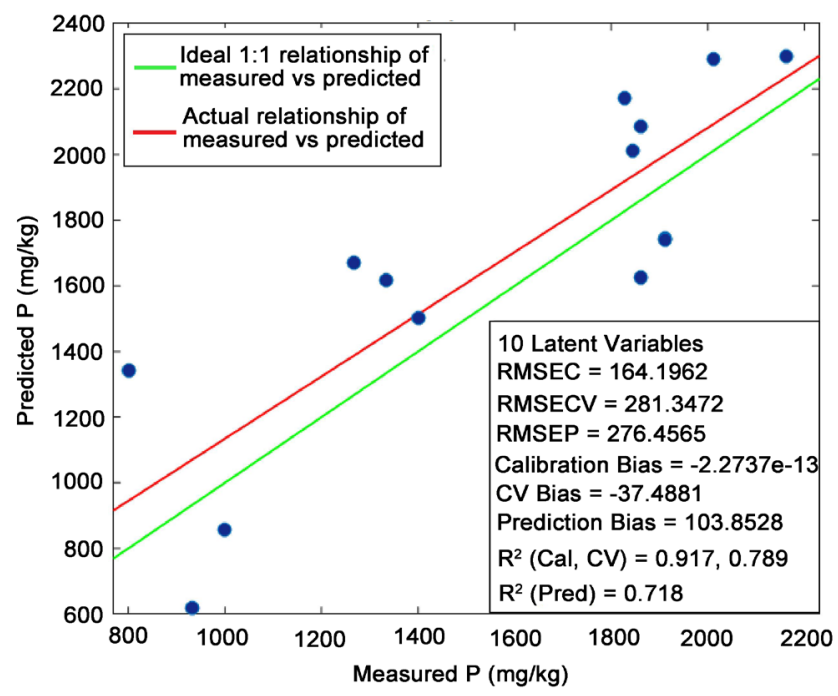

(b)

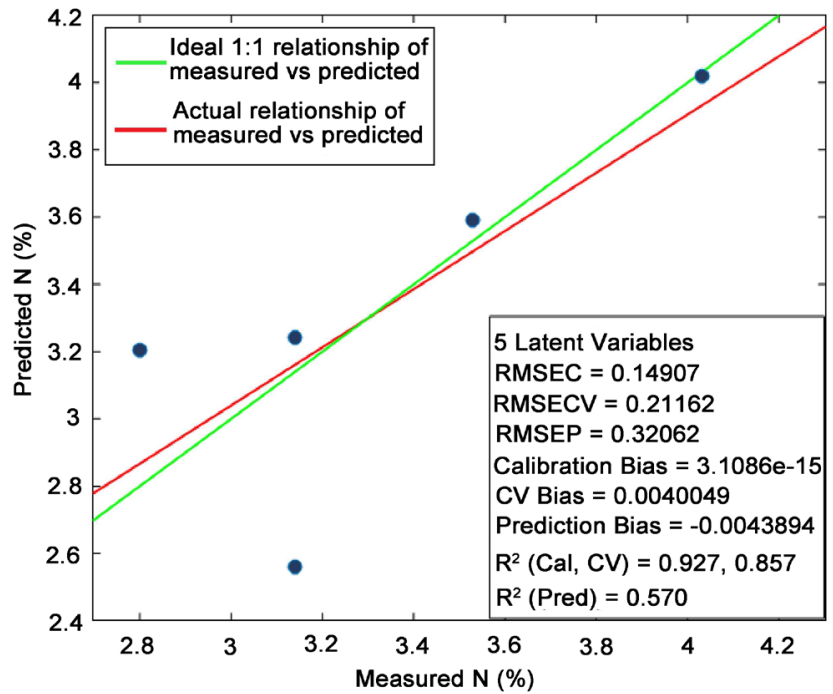

(d)

Figure 6. Predicted vs. reference plots and model data for: (a) Phosphorus calibration; (b) Phosphorus validation; (c) Nitrogen calibration; (d) Nitrogen validation.

wavelengths. Results evidence with representative dataset is given for calcium, potassium and phosphorus Okra leaves content. However models building process has left out many outliers samples. More generalized model should take into account larger data. Since the experiments were conducted under one cultural and ecological environment in the field conditions of three months with variety GB1230 of Okra seeds, methods and monitoring models still need to be verified in other ecological areas.

\section{Conclusion}

The results from this study showed that fluorescence and reflectance spectral acquisition at flowering stage are appropriate for okra yield estimation. In addition, optimal wavelengths were selected in red and far-red bands from three ex- 
citation fluorescence and specific bands reflectance derivatives spectra especially for yield estimation using spectra acquired at flowering stage as well as for potassium and phosphorus data. Macronutrients content prediction has followed a process trajectory using Monte Carlo outliers detection, Kennard-Stone data partition and IRIV approach combined to PLSR. Moderately useful models are concerned with calcium content $\left(\mathrm{RPD}_{\text {val }}=1.93, \mathrm{r}_{\mathrm{p}}=0.818\right)$ and potassium content $\left(\mathrm{RPD}_{\text {val }}=1.8, \mathrm{r}_{\mathrm{p}}=0.88\right)$. Less accuracy but acceptable with $\mathrm{RPD}_{\text {val }}=1.6, \mathrm{r}_{\mathrm{p}}=$ 0.718 was obtained in phosphorus prediction and $\mathrm{RPD}_{\text {val }}=1.46, \mathrm{r}_{\mathrm{p}}=0.56$ in nitrogen prediction. Our work gives a substantial understanding of macronutrient content relationship with some plants biochemicals by linking them to new relevant spectral bands. Thus fluorescence and reflectance spectroscopy could be a promising alternative to acquire a reliable predictive view of the macronutrient concentration of Okra leaves. Furthermore, such method could be optimized and applied on other agricultural cultures in order facilitating the rapid and easy evaluation of crops nutritional status by the development of low-cost portable devices for crops monitoring.

\section{Acknowledgements}

This research was supported by the International Science Program (ISP); the National Polytechnic Institute Houphouet-Boigny (INPHB); and the University of Nangui Abrogoua (UNA).We are grateful to the CNRA for providing seed. We would also like to express our gratitude to all research colleagues from pedology and chemistry departments, and laboratories in INPHB.

\section{References}

[1] Maghrebi, M., Nocito, F.F. and Sacchi, G.A. (2014) Monitoring Plant Nutritional Status. In: Hawkesford, M.J., Kopriva, S. and De Kok, L.J., Eds., Nutrient Use Efficiency in Plants, Springer International Publishing, Cham, 253-272. https://doi.org/10.1007/978-3-319-10635-9_10

[2] Food and Agricultural Organization (FAO) (2009) Meeting of FAO Experts Reports in June 2009.

http://www.fao.org/fileadmin/templates/wsfs/docs/expert_paper/How_to_Feed_the =World_in_2050.pdf

[3] Godfray, H.C.J., Beddington, J.R., Crute, I.R., Haddad, L., Lawrence, D., Muir, J.F. and Toulmin, C. (2010) Food Security: The Challenge of Feeding 9 Billion People. Science, 327, 812-818. https://doi.org/10.1126/science.1185383

[4] Maathuis, F.J.M. and Diatloff, E. (2013) Roles and Functions of Plant Mineral Nutrients. In: Maathuis, F.J.M., Ed., Plant Mineral Nutrients, Humana Press, Totowa, NJ, 1-21. https://doi.org/10.1007/978-1-62703-152-3_1

[5] Taiz, L. and Zeiger, E. (2010) Plant Physiology. 5th Edition, Sinauer Associates, Sunderland.

[6] Agati, G., Foschi, L., Grossi, N., Guglielminetti, L., Cerovic, Z.G. and Volterrani, M. (2013) Fluorescence-Based versus Reflectance Proximal Sensing of Nitrogen Content in Paspalum vaginatum and Zoysia matrella Turfgrasses. European Journal of Agronomy, 45, 39-51. https://doi.org/10.1016/j.eja.2012.10.011

[7] Agati, G., Foschi, L., Grossi, N. and Volterrani, M. (2015) In Field Non-Invasive 
Sensing of the Nitrogen Status in Hybrid Bermudagrass (Cynodon dactylon $\times C$. transvaalensis Burtt Davy) by a Fluorescence-Based Method. European Journal of Agronomy, 63, 89-96. https://doi.org/10.1016/j.eja.2014.11.007

[8] Diacono, M., Rubino, P. and Montemurro, F. (2013) Precision Nitrogen Management of Wheat. A Review. Agronomy for Sustainable Development, 33, 219-241. https://doi.org/10.1007/s13593-012-0111-Z

[9] Liu, F., Nie, P., Huang, M., Kong, W. and He, Y. (2011) Nondestructive Determination of Nutritional Information in Oilseed Rape Leaves Using Visible/near Infrared Spectroscopy and Multivariate Calibrations. Science China Information Sciences, 54, 598-608. https://doi.org/10.1007/s11432-011-4198-7

[10] Menesatti, P., Antonucci, F., Pallottino, F., Roccuzzo, G., Allegra, M., Stagno, F. and Intrigliolo, F. (2010) Estimation of Plant Nutritional Status by Vis-NIR Spectrophotometric Analysis on Orange Leaves [Citrus sinensis (L) Osbeck cv Tarocco]. Biosystems Engineering, 105, 448-454.

https://doi.org/10.1016/j.biosystemseng.2010.01.003

[11] Zhang, X., Liu, F., He, Y. and Gong, X. (2013) Detecting Macronutrients Content and Distribution in Oilseed Rape Leaves Based on Hyperspectral Imaging. Biosystems Engineering, 115, 56-65.

https://doi.org/10.1016/j.biosystemseng.2013.02.007

[12] Cetinkaya, H., Koc, M. and Kulak, M. (2016) Monitoring of Mineral and Polyphenol Content in Olive Leaves under Drought Conditions: Application Chemometric Techniques. Industrial Crops and Products, 88, 78-84. https://doi.org/10.1016/j.indcrop.2016.01.005

[13] Varmudy, V. (2011) Marking Survey Need to Boost Okra Exports. Department of Economics, Vivekananda College, Puttur, Karnataka.

[14] Kouassi, J., Massara, C., Sess, D., Tiahou, G., Ake, M.A. and Djohan, F. (2013a) Détermination des teneurs en fer, en calcium, en cuivre et en zinc de deux variétés de gombo. [Determination of Iron, Calcium, Copper and Zinc Contents of Two Varieties of Okra.] Bulletin de la Société Royale des Sciences de Liège, 82, 22-32. http://popups.ulg.ac.be/0037-9565/index.php?id=3990

[15] Kouassi, J., Massara, C., Sess, D., Tiahou, G. and Djohan, F. (2013b) Détermination des teneurs en Magnésium, Potassium, Manganèse et Sodium de deux variétés de gombo. [Determination of the Content in Magnesium, Potassium, Manganese and Sodium of Two Varieties of Okra (Abelmoschus esculentus).] Journal of Applied Biosciences, 67, 5219. https://doi.org/10.4314/jab.v67i0.95043

[16] Roy, A., Shrivastava, S.L. and Mandal, S.M. (2014) Functional Properties of Okra Abelmoschus esculentus L. (Moench): Traditional Claims and Scientific Evidences. Plant Science Today, 1, 121-130. https://doi.org/10.14719/pst.2014.1.3.63

[17] IFA (2000) Okra (Abelmoscus esculentus, L). In: World Fertilizer Use Manual, IFA Publications, India.

[18] Lamont, W.J. (1999) Okra-A Versatile Vegetable Crop. HortTechnology, 9, 179-184.

[19] Omotoso, S.O. and Shittu, O.S. (2008) Soil Properties, Leaf Nutrient Composition and Yield of Okra (Abelmoschus escalentas (L.) Moench) as Affected by Broiler Litter and NPK 15:15:15 Fertilizers in Ekiti State, Nigeria. International Journal of Agricultural Research, 3, 140-147. https://doi.org/10.3923/ijar.2008.140.147

[20] Law-Ogbomo, K.E. (2013) Nutrient Uptake by Abelmoschus esculentus and Its Effects on Changes in Soil Chemical Properties as Influenced by Residual Application of Fertilizer. Journal of Soil Science and Environmental Management, 4, 132-138. https://doi.org/10.5897/JSSEM11.072 
[21] Sanni, K.O. (2014) Morphological and Yield Performances of Okra (Abelmoschus esculentus) as Influenced by Soil Amended with Poultry Manure and N.P.K 15-15-15 Fertilizer in Ikorodu, Nigeria. International Journal of Horticulture, 4, 58-63.

[22] Nzikou, J.M., Mvoula-Tsieri, M., Matouba, E., Ouamba, J.M., Kapseu, C., Kapseu, C. and Desobry, S. (2006) A Study on Gumbo Seed Grown in Congo Brazzaville for Its Food and Industrial Applications. African Journal of Biotechnology, 5. http://www.ajol.info/index.php/ajb/article/view/56046

[23] CNRA (2014) Centre National de Recherche Agronomique, Bien cultiver le gombo. [Better Way to Grow Okra in the Fields in Ivory Coast. Technical Report Online.] http://www.cnra.ci/listefiche.php

[24] Zhao, N., Wu, Z., Zhang, Q., Shi, X., Ma, Q. and Qiao, Y. (2015) Optimization of Parameter Selection for Partial Least Squares Model Development. Scientific Reports, 5, 11647. https://doi.org/10.1038/srep11647

[25] Zou, X. and Zhao, J. (2015) Nondestructive Measurement in Food and Agro-Products. Springer, Beijing. https://doi.org/10.1007/978-94-017-9676-7

[26] Yun, Y.-H., Wang, W.-T., Tan, M.-L., Liang, Y.-Z., Li, H.-D., Cao, D.-S. and Xu, Q.-S. (2014) A Strategy That Iteratively Retains Informative Variables for Selecting Optimal Variable Subset in Multivariate Calibration. Analytica Chimica Acta, 807, 36-43. https://doi.org/10.1016/j.aca.2013.11.032

[27] Walkley, A. and Black, I.A. (1934) An Examination of the Degtjareff Method for Determining Soil Organic Matter, and a Proposed Modification of the Chromic Acid Titration Method. Soil Science, 37, 29-38. https://doi.org/10.1097/00010694-193401000-00003

[28] Kjeldahl, J. (1883) A New Method for the Determination of Nitrogen in Organic Matter. Journal of Analytical Chemistry, 22, 366-382.

[29] Thomas, G.W. (1982) Exchangeable Cations. Methods of Soil Analysis. Part 2. Chemical and Microbiological Properties, Agronomymonogra (methods of soil an 2), 159-165.

[30] Boyer, J. and Aubert, G. (1982) Les sols ferralitiques: facteurs de fertilité et utilisation des sols, Tome 10, ORSTOM, Paris. [Ferralitic Soils: Fertility Factors and Land Use, Vol. 10, ORSTOM, Paris.]

[31] FAO, IFA and IMPHOS (2003) Les engrais et leurs applications: Précis à l'usage des agents de vulgarisation agricole. [Fertilizers and Their Applications: Handbook for Agriculture Resource Managers.] 4th Edition, Food \& Agriculture Organisation, Rabbat.

[32] Dibi, W.G., Fotso, B., Brou, C.Y., Zoueu, J.T., Zeze, A. and Bosson, J. (2016) Fluorescence and Reflectance Spectroscopy for Early Detection of Different Mycorrhized Plantain Plants. Applied Physics Research, 8, 17.

https://doi.org/10.5539/apr.v8n3p17

[33] Brydegaard, M., Bengmark, S., Svanberg, K. and Svanberg, S. (2009) Optical Diagnosis for Integrated Advanced Glycation End Products and Malignant Disease Assessment. Swedish Patent (0900425-0), P4L09.

[34] Barnes, R., Dhanoa, M. and Lister, S. (1993) Letter: Correction to the Description of Standard Normal Variate (SNV) and De-Trend (DT) Transformations in Practical Spectroscopy with Applications in Food and beverage Analysis. 2nd Edition. Journal of Near Infrared Spectroscopy, 1, 185. https://doi.org/10.1255/jnirs.21

[35] Hruschka, W.R. (1987) Data Analysis: Wavelength Selection Methods. In: Williams, P. and Norris, K., Eds., Near-Infrared Technology in the Agricultural and Food Industries, American Association of Cereal Chemists, St. Paul, MN, 35-55. 
[36] Rieppo, L., Saarakkala, S., Närhi, T., Helminen, H.J., Jurvelin, J.S. and Rieppo, J. (2012) Application of Second Derivative Spectroscopy for Increasing Molecular Specificity of Fourier Transform Infrared Spectroscopic Imaging of Articular Cartilage. Osteoarthritis and Cartilage, 20, 451-459. https://doi.org/10.1016/j.joca.2012.01.010

[37] AOAC (1990) Official method of Analysis. Association of Official Analytical Chemists, Food Composition, Additives Natural Contaminant. Vol. 2, 15th Edition, Association of Official Analytical Chemists, Inc., USA.

[38] Pinta, M. (1973) Méthodes de référence pour la détermination des éléments minéraux dans les végétaux: Détermination des éléments $\mathrm{Ca}, \mathrm{Mg}, \mathrm{Fe}, \mathrm{Mn}, \mathrm{Zn}$ et $\mathrm{Cu}$ par absorption atomique, Oléagineux. [Standard Methods for Determining the Mineral Content of Vegetables: Determination of $\mathrm{Ca}, \mathrm{Mg}, \mathrm{Fe}, \mathrm{Mn}, \mathrm{Zn}$ and $\mathrm{Cu}$ by Atomic Absorption, Oleaginous Plants.]

[39] Cao, D.-S., Liang, Y.-Z., Xu, Q.-S., Li, H.-D. and Chen, X. (2010) A New Strategy of Outlier Detection for QSAR/QSPR. Journal of Computational Chemistry, 31, 592-602.

[40] Kennard, R.W. and Stone, L.A. (1969) Computer Aided Design of Experiments. Technometrics, 11, 137-148. https://doi.org/10.1080/00401706.1969.10490666

[41] Wu, W., Walczak, B., Massart, D.L., Heuerding, S., Erni, F., Last, I.R. and Prebble, K.A. (1996) Artificial Neural Networks in Classification of NIR Spectral Data: Design of the Training Set. Chemometrics and Intelligent Laboratory Systems, 33, 35-46. https://doi.org/10.1016/0169-7439(95)00077-1

[42] Galvao, R.K.H., Araujo, M.C.U., Jose, G.E., Pontes, M.J.C., Silva, E.C. and Saldanha, T.C.B. (2005) A Method for Calibration and Validation Subset Partitioning. Talanta, 67, 736-740. https://doi.org/10.1016/j.talanta.2005.03.025

[43] Saptoro, A., Yao, H.M., Tadé, M.O. and Vuthaluru, H.B. (2008) Prediction of Coal Hydrogen Content for Combustion Control in Power Utility Using Neural Network Approach. Chemometrics and Intelligent Laboratory Systems, 94, 149-159. https://doi.org/10.1016/j.chemolab.2008.07.007

[44] Wold, S., Martens, H. and Wold, H. (1983) The Multivariate Calibration Problem in Chemistry Solved by the PLS Method. In: Kågström, B. and Ruhe, A., Eds., Matrix Pencils, Springer Berlin Heidelberg, 286-293. https://doi.org/10.1007/BFb0062108

[45] Hulland, J. and Business, R.I.S. (1999) Use of Partial Least Squares (PLS) in Strategic Management Research: A Review of Four Recent Studies. Strategic Management Journal, 20, 195-204. https://doi.org/10.1002/(SICI)1097-0266(199902)20:2<195::AID-SMJ13>3.0.CO;2-7

[46] Cao, K.-A.L., Boitard, S. and Besse, P. (2011) Sparse PLS Discriminant Analysis: Biologically Relevant Feature Selection and Graphical Displays for Multiclass Problems. BMC Bioinformatics, 12, 1.

[47] Crockford, D.J., Keun, H.C., Smith, L.M., Holmes, E. and Nicholson, J.K. (2005) Curve-Fitting Method for Direct Quantitation of Compounds in Complex Biological Mixtures Using 1H NMR: Application in Metabonomic Toxicology Studies. Analytical Chemistry, 77, 4556-4562. https://doi.org/10.1021/ac0503456

[48] Luco, J.M. (1999) Prediction of the Brain-Blood Distribution of a Large Set of Drugs from Structurally Derived Descriptors Using Partial Least-Squares (PLS) Modeling. Journal of Chemical Information and Computer Sciences, 39, 396-404. https://doi.org/10.1021/ci980411n

[49] Mateos-Aparicio, G. (2011) Partial Least Squares (PLS) Methods: Origins, Evolution, and Application to Social Sciences. Communications in Statistics-Theory and Methods, 40, 2305-2317. https://doi.org/10.1080/03610921003778225 
[50] Williams, P.C. (2001) Implementation of Near-Infrared Technology. Near-Infrared Technology in the Agricultural and Food Industries, 2, 143-167.

[51] Malley, D.F., Martin, P.D. and Ben-Dor, E. (2004) Application in Analysis of Soils. Near-Infrared Spectroscopy in Agriculture, 44, 729-784.

[52] Li, H., Xu, Q. and Liang, Y. (2014). libPLS: An Integrated Library for Partial Least Squares Regression and Discriminant Analysis. PeerJ PrePrints, 2, e190v1. https://peerj.com/preprints/190v1.pdf

[53] Moustakas, N.K., Akoumianakis, K.A. and Passam, H.C. (2011) Patterns of Dry Biomass Accumulation and Nutrient Uptake by Okra (Abelmoschus esculentus (L.) Moench.) under Different Rates of Nitrogen Application. Australian Journal of Crop Science, 5, 993.

[54] Czarnecki, M.A. (2015) Resolution Enhancement in Second-Derivative Spectra. Applied Spectroscopy, 69, 67-74. https://doi.org/10.1366/14-07568

[55] ElMasry, G., Sun, D.-W. and Allen, P. (2012) Near-Infrared Hyperspectral Imaging for Predicting Colour, $\mathrm{pH}$ and Tenderness of Fresh Beef. Journal of Food Engineering, 110, 127-140. https://doi.org/10.1016/j.jfoodeng.2011.11.028

[56] Wu, D., Nie, P., Cuello, J.L., He, Y., Wang, Z. and Wu, H. (2011) Application of Visible and Near Infrared Spectroscopy for Rapid and Non-Invasive Quantification of Common Adulterants in Spirulina Powder. Journal of Food Engineering, 102, 278-286. https://doi.org/10.1016/j.jfoodeng.2010.09.002

[57] Weber, V.S., Araus, J.L., Cairns, J.E., Sanchez, C., Melchinger, A.E. and Orsini, E. (2012) Prediction of Grain Yield Using Reflectance Spectra of Canopy and Leaves in Maize Plants Grown under Different Water Regimes. Field Crops Research, 128, 82-90. https://doi.org/10.1016/j.fcr.2011.12.016

[58] Villatoro-Pulido, M., Moreno Rojas, R., Muñoz-Serrano, A., Cardeñosa, V., Amaro López, M.Á., Font, R. and Del Río-Celestino, M. (2012) Characterization and Prediction by Near-Infrared Reflectance of Mineral Composition of Rocket (Eruca vesicaria subsp. Sativa and Eruca vesicaria subsp. Vesicaria). Journal of the Science of Food and Agriculture, 92, 1331-1340. https://doi.org/10.1002/jsfa.4694

[59] Ward, A., Nielsen, A.L. and Møller, H. (2011) Rapid Assessment of Mineral Concentration in Meadow Grasses by Near Infrared Reflectance Spectroscopy. Sensors, 11, 4830-4839. https://doi.org/10.3390/s110504830

[60] Aldana, B.R.V. de, Criado, B.G., Ciudad, A.G. and Corona, M.E.P. (1995) Estimation of Mineral Content in Natural Grasslands by Near Infrared Reflectance Spectroscopy. Communications in Soil Science and Plant Analysis, 26, 1383-1396. https://doi.org/10.1080/00103629509369379

[61] Klančnik, K., Vogel-Mikuš, K., Kelemen, M., Vavpetič, P., Pelicon, P., Kump, P. and Gaberščik, A. (2014) Leaf Optical Properties Are Affected by the Location and Type of Deposited Biominerals. Journal of Photochemistry and Photobiology B: Biology, 140, 276-285. https://doi.org/10.1016/j.jphotobiol.2014.08.010

[62] Pal, P. and Ghosh, P. (2010) Effect of Different Sources and Levels of Potassium on Growth, Flowering and Yield of African Marigold (Tagetes erecta Linn.) cv. 'Siracole'. Indian Journal of Natural Products and Ressources, 1, 371-375.

[63] Ahanger, M.A., Agarwal, R., Tomar, N.S. and Shrivastava, M. (2015) Potassium Induces Positive Changes in Nitrogen Metabolism and Antioxidant System of Oat (Avena sativa L cultivar Kent). Journal of Plant Interactions, 10, 211-223. https://doi.org/10.1080/17429145.2015.1056260

[64] Özyiğit, Y. and Bilgen, M. (2013) Use of Spectral Reflectance Values for Determining Nitrogen, Phosphorus, and Potassium Contents of Rangeland Plants. Journal of 
Agricultural Science and Technology, 15, 1537-1545.

[65] Veneklaas, E.J., Lambers, H., Bragg, J., Finnegan, P.M., Lovelock, C.E., Plaxton, W.C. and Raven, J.A. (2012) Opportunities for Improving Phosphorus-Use Efficiency in Crop Plants. New Phytologist, 195, 306-320. https://doi.org/10.1111/j.1469-8137.2012.04190.x

[66] Balemi, T. and Negisho, K. (2012) Management of Soil Phosphorus and Plant Adaptation Mechanisms to Phosphorus Stress for Sustainable Crop Production: A Review. Journal of Soil Science and Plant Nutrition, 12, 547-562. https://doi.org/10.4067/S0718-95162012005000015

[67] Li, H., Yang, Y., Zhang, H., Chu, S., Zhang, X., Yin, D., Yu, D. and Zhang, D. (2016) A Genetic Relationship between Phosphorus Efficiency and Photosynthetic Traits in Soybean as Revealed by QTL Analysis Using a High-Density Genetic Map. Frontiers in Plant Science, 7, 924. https://doi.org/10.3389/fpls.2016.00924

[68] Ulrychová, M. and Sosnová, V. (2008) Effect of Phosphorus Deficiency on Anthocyanin Content in Tomato Plants. Biologia Plantarum, 12, 231-235. https://doi.org/10.1007/BF02920805

[69] Stewart, A.J., Chapman, W., Jenkins, G.I., Graham, I., Martin, T. and Crozier, A. (2001) The Effect of Nitrogen and Phosphorus Deficiency on Flavonol Accumulation in Plant Tissues. Plant, Cell and Environment, 24, 1189-1197. https://doi.org/10.1046/j.1365-3040.2001.00768.x

[70] Li, L., Lu, J., Wang, S., Ma, Y., Wei, Q., Li, X. and Ren, T. (2016) Methods for Estimating Leaf Nitrogen Concentration of Winter Oilseed Rape (Brassica napus L.) Using In Situ Leaf Spectroscopy. Industrial Crops and Products, 91, 194-204. https://doi.org/10.1016/j.indcrop.2016.07.008

[71] Rotbart, N., Schmilovitch, Z., Cohen, Y., Alchanatis, V., Erel, R., Ignat, T. and Yermiyahu, U. (2013) Estimating Olive Leaf Nitrogen Concentration Using Visible and Near-Infrared Spectral Reflectance. Biosystems Engineering, 114, 426-434. https://doi.org/10.1016/j.biosystemseng.2012.09.005

[72] Vigneau, N., Ecarnot, M., Rabatel, G. and Roumet, P. (2011) Potential of Field Hyperspectral Imaging as a Non-Destructive Method to Assess Leaf Nitrogen Content in Wheat. Field Crops Research, 122, 25-31. https://doi.org/10.1016/j.fcr.2011.02.003

[73] Wang, S., Li, W., Li, J. and Liu, X. (2013) Prediction of Soil Texture Using FT-NIR Spectroscopy and PXRF Spectrometry with Data Fusion. Soil Science, 178, 626-638. https://doi.org/10.1097/SS.0000000000000026 